\title{
PENINGKATAN HASIL BELAJAR SISWA MENGGUNAKAN MEDIA KARTU POSITIF NEGATIF PADA MATA PELAJARAN MATEMATIKA POKOK BAHASAN PENJUMLAHAN BILANGAN BULAT KELAS IV DI SDN 04 MAMBEN LAUK TAHUN PELAJARAN 2016/2017
}

\author{
Oleh: Ittihad* \\ Dosen STIT Palapa Nusantara Lombok NTB
}

\begin{abstract}
Abstrak : Research has been conducted on the Improvement of Student Learning Outcomes Using Positive Card Cards On Mathematics Subjects Summation of Sum Total Class IV Students at SDN 04 Mamben Lauk Lesson Year 2016/2017. The purpose of this research is to know how to Increase Student Learning Result Using Positive Negative Positive Media on Mathematics Subject Matter of Sum Sumed of Student of Class IV in SDN 04 Mamben Lauk Lesson Year 2016/2017. The types of research used are classroom action research and data analysis techniques used in this research are reduction, data presentation, verification, and development of instruments used to summarize data, encode, straighten the theme and make clusters about the data about improving learning outcomes Fourth grade students of SDN 04 Mamben Lauk. Based on the results of the study found a significant result that is the increase in student learning outcomes after using the positive negative card media many of the students whose learning outcomes to be better than before, the original average value is 6.3 after conducting research the average value to be 8.2 . There is an increase in student learning outcomes in mathematics subjects of the sum of integers after the application of this positive negative card media.

Kata Kunci : Peningkatan Hasil Belajar, Media Kartu Positif, Matematika, Penjumlahan Bilangan Bulat.
\end{abstract}

\section{PENDAHULUAN}

Pendidikan adalah suatu proses dalam rangka mempengaruhi peserta didik supaya mampu menyesuaikan diri sebaik mungkin dengan lingkungan, dan dengan demikian akan menimbulkan perubahan dalam dirinya yang memungkinkannya untuk berfungsi secara normal dalam kehidupan masyarakat. Dalam UU No. 2 Tahun 1989 disebutkan bahwa Pendidikan Nasional bertujuan mencerdaskan kehidupan bangsa dan mengembangkan manusia Indonesia seutuhnya, yaitu manusia yang beriman dan bertaqwa terhadap Tuhan Yang Maha 
Esa dan berbudi pekerti luhur, memiliki pengetahuan dan keterampilan, kesehatan jasmani dan rohani, keperibadian yang mantap dan mandiri, serta kebangsaan.

Tujuan di atas tidak dapat tercapai jika proses interaksi belajar mengajar tidak pernah berlangsung dalam pendidikan. Guru dan siswa adalah dua unsur yang terlibat langsung dalam proses ini. Oleh karena itu disinilah peranan guru diperlukan yaitu bagaimana menciptakan interaksi belajar mengajar yang kondusif. Begitu pula dalam pembelajaran matematika di Sekolah Dasar, seorang guru dalam menciptakan interaksi belajar mengajar yang kondusif perlu memperhatikan karakteristik dari peserta didik $^{1}$.

Anak usia Sekolah Dasar berada pada tahap operasi konkrit yang ditandai oleh proses berfikir yang masih tergantung pada hal-hal yang konkrit. Oleh karena itu, guru dituntut untuk menggunakan media di dalam proses belajar mengajar. Karena media pembelajaran dapat menjembatani pola fikir siswa yaitu dari hal-hal yang bersifat abstrak ke hal-hal yang bersifat konkrit. Akan tetapi, yang menjadi permasalahan yaitu masih banyak guru yang bingung dalam menentukan media yang tepat untuk digunakan dalam proses belajar mengajar.

Berdasarkan hasil observasi di kelas IV SDN 04 Mamben Lauk, diketahui bahwa guru masih bingung dalam menentukan media yang tepat untuk digunakan dalam proses belajar mengajar, khususnya pada mata pelajaran matematika pokok bahasan penjumlahan bilangan bulat. Guru hanya mengikuti petunjuk dari buku paket yang sudah ada yaitu menggunakan garis bilangan, itupun garis bilangan tersebut hanya digambar di papan tulis sehingga hasil belajar dari para siswa pada mata pelajaran matematika pokok bahasan penjumlahan bilangan belum memuaskan.

Berdasarkan penjelasan di atas, maka pembelajaran penjumlahan bilangan bulat di kelas IV SDN 04 Mamben Lauk, perlu mendapat perhatian sehingga akan diperoleh hasil yang memuaskan. Salah satu upaya yang dapat dilakukan adalah dengan menggunakan media dalam kegiatan pembelajaran. Salah satu

${ }^{1}$ Desmita, Strategi Perkembangan Belajar Mengajar (Jakarta:Rineka Cipta, 2009). Hlm. 25 
media yang dapat digunakan dalam pembelajaran penjumlahan bilangan bulat adalah kartu positif negatif.

Dengan adanya kartu positif negatif ini, siswa dilatih untuk menemukan sendiri konsep penjumlahan bilangan bulat dengan menggunakan media yang sederhana ini, siswa dapat mempraktekkan langsung secara konkrit sehingga membantu siswa memahami konsep penjumlahan pada bilangan bulat.

Berdasarkan latar belakang di atas, peneliti tertarik untuk melakukan penelitian dengan judul: "Peningkatkan Hasil Belajar Siswa Menggunakan Media Kartu Positif Negatif Pada Mata Pelajaran Matematika Pokok Bahasan Penjumlahan Bilangan Bulat Siswa Kelas IV di SDN 04 Mamben Lauk Tahun Pelajaran 2016/2017”.

\section{Belajar Mengajar}

Pada dasarnya dalam proses belajar mengajar ada tiga komponen penting yaitu pengajar, siswa dan bahan ajar yang diberikan oleh pengajar. Agar proses belajar mengajar sesuai dengan apa yang diharapkan, maka baik siswa maupun tenaga pengajar perlu memiliki sikap, kemampuan dan keterampilan yang mendukung proses belajar mengajar.

Proses belajar mengajar adalah suatu kegiatan antara siswa dengan guru. Dalam kegiatan ini terjadi interaksi yakni hubungan antara guru dengan siswa dalam situasi instruksional yaitu suasana yang bersifat pembelajaran. ${ }^{2}$

Berdasarkan pendapat-pendapat di atas, maka dapat ditarik kesimpulan bahwa proses belajar mengajar merupakan interaksi yang terjadi antara siswa dengan guru dalam sebuah situasi yang disebut juga dengan pembelajaran.

Belajar adalah suatu proses aktivitas yang dapat membawa perubahan individu. ${ }^{3}$ Adapu pendapat yang lain mendefinisikan belajar adalah suatu aktivvitas mental yang berlangsung dalam interaksi aktif dengan lingkungan yang menghasilkan perubahan dalam pengetahuan, keterampilan dan sikap.

${ }^{2}$ Muhibbin Syah, Psikologi Belajar ( Jakarta :PT.Rasa Grafindo Persada, 2003), 239.

${ }^{3}$ Roestiyah, Strategi Belajar Mengajar (Jakarta:Rineka Cipta, 1990), 141. 
Berdasarkan beberapa pengertian di atas, maka dapat disimpulkan bahwa belajar merupakan suatu proses yang ditandai dengan adanya perubahan sikap, kemampuan dan keterampilan.

\section{Pembelajaran Matematika di Sekolah Dasar}

Matematika merupakan ilmu universal yang mendasari perkembangan teknologi modern, mempunyai peranan penting dalam berbagai disiplin dan memajukan daya fikir manusia. Matematika perlu diberikan kepada semua peserta didik mulai dari Sekolah Dasar untuk membekali peserta didik dengan kemampuan berfikir logis, analisis, sistematis, krtisis dan kreatif, serta kemampuan bekerja sama.

Adapun tujuan mata pelajaran matematika pada jenjang pendidikan dasar agar peserta didik memiliki kemampuan, yaitu : (1) Memahami konsep matematika, menjelaskan keterkaitan antar konsep dan mengaplikasikan konsep atau algoritma, secara luwes, akurat, efisien, dan tepat dalam pemecahan masalah, (2) menggunakan penalaran pada pola dan sifat, melakukan manipulasi matematika dalam membuat generalisai, menyusun bukti, atau menjelaskan gagasan dan pernyataan matematika, (3) memecahkan masalah yang meliputi kemampuan memahami masalah, merancang model matematika, menyelesaikan model dan menafsirkan solusi yang diperoleh, (4) mengomunikasikan gagasan dengan symbol, tabel, diagram, atau media lain untuk memperjelas keadaan atau masalah, (5) memiliki sikap menghargai kegunaan matematika dalam kehidupan, yaitu memiliki rasa ingin tahu, perhatian, dan minat dalam mempelajari matematika, serta sikap ulet dan percaya diri dalam pemecahan masalah. ${ }^{4}$

Agar tujuan itu dapat tercapai, maka harus dilakukan berbagai macam kegiatan pembelajaran matematika, baik dari segi pendekatan, strategi belajar mengajar, maupun metode mengajar yang digunakan. Kegiatan-kegiatan tersebut harus dapat menunjang tercapainya tujuan yang diharapkan. Tujuan tersebut dianggap tercapai bila siswa telah memiliki sejumlah kemampuan dibidang matematika.

\section{Hasil Belajar}

${ }^{4}$ Depdiknas. Tujuan Matematika di Sekolah Dasar (Jakarta:.depdiknas, 2006) 
Hasil belajar merupakan suatu prestasi yang dicapai seseorang dalam mengikuti proses belajar atau hasil belajar adalah perubahan yang terjadi dalam diri individu. Perubahan yang terjadi biasanya perubahan yang terarah dan bertujuan, yaitu untuk mencapai sesuatu yang baik dan baru sebelumnya. belajar adalah tingkah laku baru yang timbul, misalnya dari tidak tahu menjadi tahu, timbul pengertian-pengertian baru, perubahan dalam sikap, kebiasaan, keterampilan, kesanggupan,menghargai, perkembangan sifat-sifat sosial dan perubahan jasmaniah. ${ }^{5}$

\section{Media Pembelajaran}

Kata media berasal dari bahasa latin medium yang secara harfiah berarti tengah, perantara, atau pengantar. Atau dengan kata lain media adalah perantara atau pengantar pesan dari pengirim pesan kepada penerima pesan. ${ }^{6}$ Jadi secara bahasa media berarti pengantar pesan dari pengirim kepada penerima pesan. Secara lebih khusus, pengertian media dalam proses belajar mengajar cenderung diartikan sebagai alat-alat grafis, photografis, atau elektronis untuk menagkap, memproses dan menyusun kembali informasi visual atau verbal. ${ }^{7}$

Media pembelajaran adalah segala sesuatu yang dapat digunakan untuk menyalurkan pesan dari pengirim ke penerima sehingga merangsang fikiran, perasaan, perhatian dan minat serta kemauan peserta didik sedemikian rupa sehingga proses belajar terjadi dalam rangka mencapai tujuan pembelajaran secara efektif. $^{8}$

\section{Bilangan Bulat}

Bilangan bulat adalah suatu bilangan atau himpunan yang merupakan gabungan dari himpunan bilangan asli dan nol, dimana himpunan bilangan bulat ini dapat ditulis $(\ldots .,-4,-3,-2,-1,0,1,2,3,4, \ldots .$.$) . himpunan bilangan asli sebagian$

${ }^{5}$ Oemar Hamalik, Psikologi Belajar Mengajar ( Bandung: Sinar Baru Algensindo, 1998), 21.

${ }^{6}$ Sutikno SobriF \& Athurrahman Pupuh. Strategi Belajar Mengajar ( Bandung PT.Refika Aditama, 2007), 65.

${ }^{7}$ Arsyad Azhar, Media Pembelajaran (Jakarta: Rajawali Press, 2000),3.

${ }^{8}$ Sukiman. Pengembangan Media Pembelajaran (Yogyakarta:Pedagogia, 2012),29. 
dari himpunan bulat disebut himpunan bilangan bulat positif, ditulis $(1,2,3,4, \ldots)$, himpunan bilangan nol dapat ditulis (0), sedangkan himpunan bilangan bulat negatif dapat ditulis $(\ldots,-1,-2,-3,-4, \ldots .$.$) . Jika bilangan asli dapat dikatakan$ sebagai jarak berarah ke kanan pada garis bilangan, maka untuk bilangan bulat dapat dikatakan sebagai jarak berarah ke kanan dan ke kiri pada garis bilangan yang dimulai dengan 0 yang kemudian mengukur sigma-sigma garis yang sama ke kanan diberi tanda $1,2,3,4, \ldots$ dan ke kiri diberi tanda $-1,-2,-3,-4, \ldots$.

\section{Kartu Positif Negatif}

Kartu positif negatif merupakan salah satu media yang murah dan dekat dengan lingkungan sehari-hari kita.Kartu positif negatif terbuat dari kertas manila yang diberi simbol-simbol positif dan negatif. Adapun wujud kartu positif negatif ini seperti gambar di bawah ini

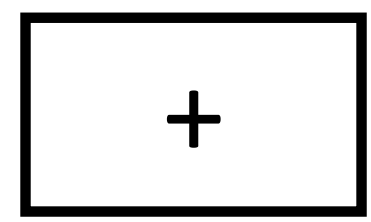

Gambar 1

Kartu Bertanda Positif

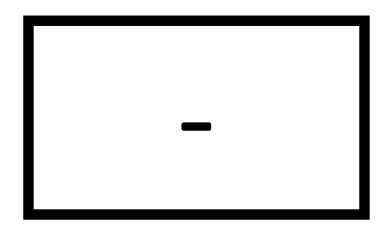

Gambar 2

Kartu Bertanda Negatif

Adapun penerapan kartu positif negatif ini dalam pembelajaran yaitu:

1. Secara berpasangan siswa pingsut atau melakukan undian untuk menentukan siapa yang memiliki hak pilih pertama (pemenang)

2. Pemenang akan mengambil kartu lebih dulu, jumlah kartunya bebas. Yang kalah mengambil kartu yang lain setelah pemenang. Misalkan dari hasil kegiatan itu diperoleh kartu bertanda negatif sebanyak 5 dan kartu bertanda positif sebanyak 3 .

3. Secara berpasangan, mereka mengitung bersama-sama

a. Anak pertama meletakkan kartu “"-,-,-,-,““ di atas meja

b. Anak kedua meletakkan kartu ",,+++ " di atas kartu bertanda negatif, sehingga terbentuk tiga pasang kartu positif dan negatif, serta dua kartu lain yang tidak berpasangan

c. Tulis proses kegiatan itu secara simbolik dengan " $(-5)+3=\ldots$ ” 
4. Banyak kartu yang tidak berpasangan itu menunjukkan jawaban dari soal itu. Karena ada dua kartu bertanda negatif yang tidak berpasangan, maka jawaban dari “( $(-5)+3=\ldots$.." adalah -2 .

\section{Rancangan Penelitian}

Adapun beberapa ahli yang mengemukakan model penulisan tindakan kelas dengan bagan yang berbeda, namun secara garis besar terdapat empat tahapan yang lazim dilalui, yaitu; 1) Perencanaan (Planning), 2) Pelaksanaan (Akting), 3) Pengamatan (Observing), 4) Refleksi (Reflecting). ${ }^{9}$ Penulisan tindakan kelas ini dilaksanakan dalam bentuk 2 , dimana di dalamnya terdapat empat tahapan utama kegiatan, yaitu perencanaan, tindakan, pengamatan, dan refleksi yang dapat digambarkan sebagai berikut:

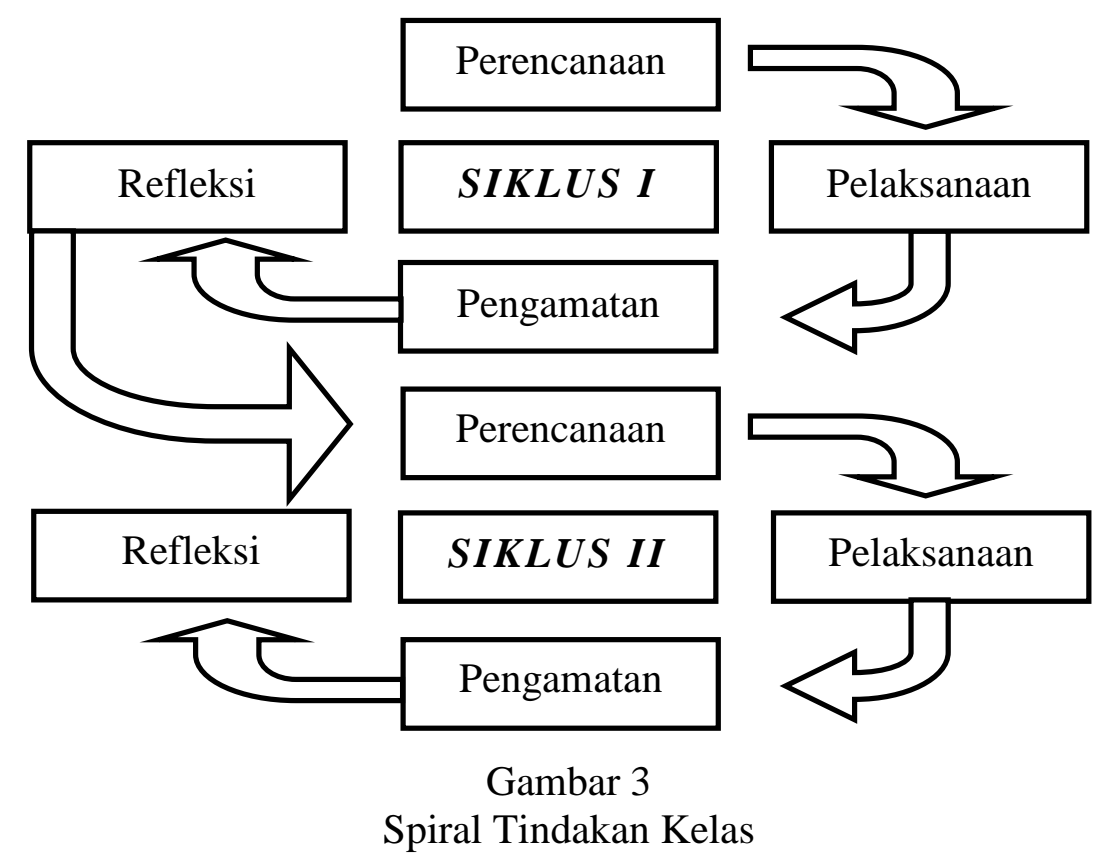

\section{Tekhnik Pengumpulan Data}

Data-data yang diperlukan dalam suatu penulisan diperoleh dengan menggunakan teknisk atau metode pengumpulan data. Metode pengumpulan data

\footnotetext{
${ }^{9}$ Arikunto, dkk. Penelitian Tindakan Kelas (Jakarta : Bumi Aksara, 2009), 16.
} 
adalah cara-cara yang dapat digunakan oleh penulis untuk mengumpulkan data. ${ }^{10}$ Teknik pengumpulan data yang digunakan dalam penulisan ini adalah Metode Observasi, wawancara dokumentasi.

\section{Tekhnik Analisis Data}

Analisis kualitatif adalah upaya yang dilakukan dengan jalan bekerja dengan data, mengorganisasikan data, memilah-milahnya menjadi satuan yang dapat dikelola, mensensintesiskannya, mencari dan menemukan pola, menemukan apa yang penting dan apa yang dipelajari, dan memutuskan apa yang diceritakan kepada orang lain.

Aktivitas dalam analisis data yaitu data reduksi (data reduction), penyajian data (data dispelay) dan penarikan kesimpulan (data concehation draming).

\section{Hasil Penelitian Dan Pembahasan}

\section{Siklus I (Pertama)}

Tabel 1 :

Hasil rata-rata aktivitas belajar siswa pada siklus I pertemuan pertama

\begin{tabular}{|c|c|c|c|c|c|c|c|c|}
\hline \multirow{2}{*}{ No } & \multirow{2}{*}{ Nama Siswa } & \multicolumn{5}{|c|}{ Perilaku Yang Diamati } & \multirow{2}{*}{ Jumlah } & \multirow{2}{*}{ Kategori } \\
\hline & & 1 & 2 & 3 & 4 & 5 & & \\
\hline 1 & ADAM ARSYAD S. & 2 & 3 & 2 & 3 & 2 & 12 & Kurang Aktif \\
\hline 2 & $\begin{array}{l}\text { AMELIA } \\
\text { SALSABILA }\end{array}$ & 4 & 3 & 3 & 3 & 3 & 16 & Cukup Aktif \\
\hline 3 & AMRINA RASYADA & 4 & 3 & 3 & 3 & 2 & 15 & Cukup Aktif \\
\hline 4 & ARIF BUDIONO & 4 & 3 & 3 & 3 & 2 & 15 & Cukup Aktif \\
\hline 5 & AULIA ASTI I. & 4 & 4 & 3 & 3 & 3 & 17 & Aktif \\
\hline 6 & DEWI ARTIKA & 4 & 3 & 3 & 3 & 3 & 16 & Cukup Aktif \\
\hline 7 & EGI AZHARI & 3 & 3 & 3 & 2 & 2 & 13 & Kurang Aktif \\
\hline 8 & $\begin{array}{l}\text { ENDAR } \\
\text { SUHERMAN }\end{array}$ & 4 & 4 & 3 & 4 & 3 & 18 & Aktif \\
\hline 9 & $\begin{array}{l}\text { ENDI ALWAN } \\
\text { HAYADI }\end{array}$ & 3 & 3 & 2 & 2 & 3 & 13 & Kurang Aktif \\
\hline 10 & HARYATI & 4 & 3 & 3 & 3 & 3 & 16 & Cukup Aktif \\
\hline 11 & M. IRFAN EFENDI & 4 & 3 & 3 & 4 & 2 & 16 & Cukup Aktif \\
\hline 12 & M. PAEZAL & 4 & 3 & 3 & 3 & 3 & 16 & Cukup Aktif \\
\hline
\end{tabular}

10 Arikunto, Suharsimi. Prosedur Penelitian Suatu Pendekatan Prakek ( Jakarta: Rineka Cipta, 2002), 100. 


\begin{tabular}{|l|l|c|c|c|c|c|c|c|}
13 & $\begin{array}{l}\text { M. ZAINUL } \\
\text { ALFIADI }\end{array}$ & 4 & 3 & 2 & 3 & 2 & 14 & Cukup Aktif \\
\hline 14 & $\begin{array}{l}\text { NESA SHAHIRA } \\
\text { PUTRI }\end{array}$ & 3 & 3 & 2 & 3 & 2 & 13 & Kurang Aktif \\
\hline $\begin{array}{l}\text { NUR ALFI } \\
\text { FARHANI }\end{array}$ & 3 & 3 & 3 & 3 & 2 & 14 & Cukup Aktif \\
\hline 16 & REZA ADITYA S.A. & 3 & 3 & 2 & 3 & 2 & 13 & Kurang Aktif \\
\hline 17 & RIZKI WAHYUDI & 3 & 3 & 3 & 3 & 3 & 15 & Cukup Aktif \\
\hline 18 & SAOMI HAFIZAH & 4 & 3 & 4 & 3 & 4 & 18 & Aktif \\
\hline 19 & SELLY SAPUTRI & 4 & 3 & 3 & 3 & 3 & 16 & Cukup Aktif \\
\hline 20 & SITI NURHIDAYATI & 4 & 3 & 3 & 2 & 2 & 14 & Cukup Aktif \\
\hline 21 & SYIFA'UL FADILA & 4 & 3 & 2 & 3 & 3 & 15 & Cukup Aktif \\
\hline
\end{tabular}

Analisis Data:

$$
M=\frac{\sum x}{n}=\frac{315}{21}=15
$$

Jadi, rata-rata aktivitas belajar siswa pada siklus I pertemuan pertama sebesar 15, kategori cukup aktif. Oleh karena itu, aktivitas belajar siswa pada pertemuan berikutnya perlu ditingkatkan

Pertemuan kedua

Proses belajar mengajar pada siklus I pertemuan kedua ini berlangsung selama 2 jam pelajaran atau 2 x 35 menit. Materi yang dibahas pada pertemuan kedua ini penjumlahan bilangan bulat adalah sebagai berikut:

1) Terjalinnya komunikasi yang baik antara sisiwa dengan yang lainnya sehingga ada peningkatan dibandingkan dengan pertemuan pertama. Hal ini disebabkan karena guru memberikan motivasi kepada siswa untuk lebih berani mengemukakan pendapatnya masing-masing.

2) Para siswa lebih semangat mengikuti pelajaran itu terlihat karena tidak ada siswa yang bermain-main. 
3) Terbentuknya aktivitas siswa dalam berdiskusi sehinnga ada peningkatan dibandingkan dengan pertemuan pertama disebakan karena guru memberikan motivasi kepada siswa untuk mendemonstrasikan konsep yang telah diterima.

4) Kesiapan siswa menerima pelajaran sudah lebih baik dari pertemuan pertama. Hal ini disebabkan karena guru memberikan tugas kepada siswa sehingga pelajaran yang telah dipelajari dapat diulang di rumah.

5) Kerjasama kelompok sudah ada peningkatan disebabkan guru memberikan penjelasan tentang pentingnya kekompakan dalam kelompok dan pembagian tugas dalam kelompok agar semua anggota kelompok memiliki taggung jawab yang sama.

6) Interaksi siswa dengan guru sudah cukup aktif, disebabkan guru sudah menjelaskan metode yang digunakan dan hal-hal apa saja yang harus dilakukan siswa dalam proses belajar mengajar.

7) Partisipasi siswa menyimpulkan hasil belajar sudah baik, siswa sudah berani mencatat kesimpulan dengan bahasanya sendiri walaupun belum sempurna.

\section{Siklus II (Kedua)}

Tabel 2 :

Hasil rata-rata aktivitas belajar siswa siklus II pertemuan pertama

\begin{tabular}{|c|c|c|c|c|c|c|c|c|}
\hline \multirow{2}{*}{ NO. } & \multirow{2}{*}{ NAMA SISWA } & \multicolumn{5}{|c|}{ Perilaku Yang Diamati } & \multirow{2}{*}{ Jumlah } & \multirow{2}{*}{ Kategori } \\
\hline & & 1 & 2 & 3 & 4 & 5 & & \\
\hline 1. & $\begin{array}{l}\text { ADAM ARSYAD } \\
\text { S. }\end{array}$ & 3 & 3 & 3 & 3 & 3 & 15 & Cukup Aktif \\
\hline 2. & $\begin{array}{l}\text { AMELIA } \\
\text { SALSABILA }\end{array}$ & 4 & 4 & 4 & 4 & 3 & 19 & Aktif \\
\hline 3. & $\begin{array}{l}\text { AMRINA } \\
\text { RASYADA }\end{array}$ & 4 & 3 & 3 & 3 & 3 & 16 & Cukup Aktif \\
\hline 4. & ARIF BUDIONO & 4 & 4 & 4 & 3 & 4 & 19 & Aktif \\
\hline 5. & AULIA ASTI I. & 4 & 4 & 3 & 3 & 3 & 17 & Aktif \\
\hline 6. & DEWI ARTIKA & 4 & 4 & 4 & 4 & 3 & 19 & Aktif \\
\hline 7. & EGI AZHARI & 3 & 3 & 3 & 3 & 2 & 14 & Cukup Aktif \\
\hline 8. & $\begin{array}{l}\text { ENDAR } \\
\text { SUHERMAN }\end{array}$ & 4 & 4 & 4 & 4 & 3 & 19 & Aktif \\
\hline 9. & $\begin{array}{l}\text { ENDI ALWAN } \\
\text { HAYADI }\end{array}$ & 3 & 3 & 3 & 3 & 3 & 15 & Cukup Aktif \\
\hline 10. & HARYATI & 4 & 4 & 4 & 4 & 3 & 19 & Aktif \\
\hline 11. & $\begin{array}{l}\text { M. IRFAN } \\
\text { EFENDI }\end{array}$ & 4 & 3 & 4 & 4 & 4 & 19 & Aktif \\
\hline
\end{tabular}




\begin{tabular}{|l|l|c|c|c|c|c|c|l|}
\hline 12. & M. PAEZAL & 4 & 3 & 3 & 3 & 3 & 16 & Cukup Aktif \\
\hline 13. & $\begin{array}{l}\text { M. ZAINUL } \\
\text { ALFIADI }\end{array}$ & 4 & 3 & 3 & 3 & 2 & 15 & Cukup Aktif \\
\hline 14. & $\begin{array}{l}\text { NESA SHAHIRA } \\
\text { PUTRI }\end{array}$ & 3 & 3 & 3 & 3 & 2 & 14 & Cukup Aktif \\
\hline 15. & $\begin{array}{l}\text { NUR ALFI } \\
\text { FARHANI }\end{array}$ & 3 & 4 & 3 & 3 & 3 & 16 & Cukup Aktif \\
\hline 16. & $\begin{array}{l}\text { REZA ADITYA S. } \\
\text { A. }\end{array}$ & 3 & 3 & 2 & 3 & 2 & 13 & Kurang Aktif \\
\hline 17. & RIZKI WAHYUDI & 3 & 3 & 3 & 3 & 3 & 15 & Cukup Aktif \\
\hline 18. & SAOMI HAFIZAH & 4 & 4 & 4 & 4 & 4 & 20 & Sangat Aktif \\
\hline 19. & SELLY SAPUTRI & 4 & 3 & 4 & 3 & 3 & 17 & Aktif \\
\hline 20. & $\begin{array}{l}\text { SITI } \\
\text { NURHIDAYATI }\end{array}$ & 4 & 3 & 3 & 3 & 3 & 16 & Cukup Aktif \\
\hline 21 & $\begin{array}{l}\text { SYIFA'UL } \\
\text { FADILA }\end{array}$ & 4 & 4 & 3 & 4 & 3 & 18 & Aktif \\
\hline & Jumlah & 77 & 72 & 70 & 70 & 62 & 351 & \\
\hline & Nilai rata-rata & 3.7 & 3.4 & 3.3 & 3.3 & 3.0 & 16,71 & \\
\hline
\end{tabular}

\section{Analisis Data:}

$$
M=\frac{\sum x}{n}=\frac{351}{21}=16.71
$$

Jadi, rata-rata aktivitas belajar siswa pada siklus II pertemuan pertama sebesar 16,71. Ini berarti bahwa kategori aktivitas belajar siswa pada siklus II pertemuan pertama ini termasuk kategori cukup aktif.

\section{Pembahasan Hasil Penelitian}

Adanya perbedaan hasil pembelajaran pada siklus I dan siklus dua menjadi indikator bahwa terjadi perbaikan pembelajaran atas pola pembelajaran yang dilakukan. Hasil belajar dengan pola yang diterapkan dan hasil belajar pada siklus ke II dengan pola dan pendekatan perbaikan pembelajaran dapat dilihat pada table di bawah ini :

1. Perbaikan siklus I dan II pada Pada Mata Pelajaran Matematika Pokok Bahasan Penjumlahan Bilangan Bulat Kelas IV di SDN 04 Mamben Lauk :

Tabel 3 :

Hasil Nilai Siklus I dan II 


\begin{tabular}{|c|c|c|c|c|c|}
\hline \multirow[t]{2}{*}{ No } & \multirow{2}{*}{ Nama Siswa } & \multirow[t]{2}{*}{$\mathrm{L} / \mathrm{P}$} & \multicolumn{2}{|c|}{$\begin{array}{c}\text { Mata Pelajaran } \\
\text { Matematika }\end{array}$} & \multirow[t]{2}{*}{ Ket } \\
\hline & & & Siklus I & Siklus II & \\
\hline 1 & 2 & 3 & 4 & 5 & \\
\hline 1 & ADAM ARSYAD S. & $\mathrm{L}$ & 60 & 100 & \\
\hline 2 & AMELIA SALSABILA & $\mathrm{P}$ & 60 & 80 & \\
\hline 3 & AMRINA RASYADA & $\mathrm{P}$ & 60 & 80 & \\
\hline 4 & ARIF BUDIONO & $\mathrm{L}$ & 70 & 50 & \\
\hline 5 & AULIA ASTI I. & $\mathrm{P}$ & 70 & 80 & \\
\hline 6 & DEWI ARTIKA & $P$ & 60 & 90 & \\
\hline 7 & EGI AZHARI & $\mathrm{L}$ & 70 & 80 & \\
\hline 8 & ENDAR SUHERMAN & $\mathrm{L}$ & 70 & 100 & \\
\hline 9 & ENDI ALWAN HAYADI & $\mathrm{L}$ & 70 & 60 & \\
\hline 10 & HARYATI & $\mathrm{P}$ & 60 & 70 & \\
\hline 11 & M. IRFAN EFENDI & $\mathrm{L}$ & 70 & 70 & \\
\hline 12 & M. PAEZAL & $\mathrm{L}$ & 60 & 100 & \\
\hline 13 & M. ZAINUL ALFIADI & $\mathrm{L}$ & 60 & 80 & \\
\hline 14 & NESA SHAHIRA PUTRI & $\mathrm{P}$ & 60 & 100 & \\
\hline 15 & NUR ALFI FARHANI & $\mathrm{P}$ & 60 & 100 & \\
\hline 16 & REZA ADITYA S.A. & $\mathrm{L}$ & 70 & 100 & \\
\hline 17 & RIZKI WAHYUDI & $\mathrm{L}$ & 50 & 60 & \\
\hline 18 & SAOMI HAFIZAH & $\mathrm{P}$ & 70 & 80 & \\
\hline 19 & SELLY SAPUTRI & $\mathrm{P}$ & 70 & 60 & \\
\hline 20 & SITI NURHIDAYATI & $\mathrm{P}$ & 60 & 50 & \\
\hline 21 & $\begin{array}{l}\text { SYIFA'UL FADILA } \\
\end{array}$ & $\mathrm{L}$ & 60 & 80 & \\
\hline \multicolumn{2}{|c|}{ Jumlah } & & 1340 & 1740 & \\
\hline \multicolumn{2}{|c|}{ Rata-rata } & & 6,3 & 8,2 & \\
\hline
\end{tabular}

\section{Hasil Penelitian siklus I}

\section{Analisis}

Berdasarkan hasil penelitian dan hasil analisa data yang diperoleh maka peneliti dapat menganalisis paelaksanaan pembelajaran Mata Pelajaran Matematika Pokok Bahasan Penjumlahan Bilangan Bulat Kelas IV di SDN 04 Mamben Lauk dengan menggunakan Media Kartu Positif Negatif masih dilakukan secara kaku. Guru belum dapat menemukan pendekatan pembelajaran, metode serta pengembangan strategi pembelajaran untuk dapat meningkatkan pemahaman, semangat serta hasil belajar siswa. Adanya kartu positif negatif masih diterpakan dengan secara manual dan pembelajaran masih bersifat satu arah, artinya guru tidak memberikan kesempatan kepada siswa untuk memainkan peran lebih dalam proses pembelajaran.

\section{Sintesis}


Dari hasil analisis di atas pada siklus pertama ini menunjukkan bahwa peran guru dalam mengembangkan pembelajaran dengan berbagai pendekatan masih sangat kurang,. Metode yang digunakan masih monoton dan tidak bervariasi sehingga siswa sulit memahami pelajaran yang diberikan. Tidak adanya penggunaan metode bermain dalam pembelajaran, masih tidak dapat menggunakan kartu positif negatif secara maksimal, sedikitnya peran siswa dalam menemukan sendiri yang pada akhirnya tidak dapat meningkatkan kreatifitas siswa dalam menerima materi yang diajarkan. Adanya kartu positif negatif ini tentunya akan memberikan pengaruh besar dalam meningkatkan hasil belajar siswa khususnya dalam memahamia mata pelajaran matematika pokok bahasan penjumlahan. Akan tetapi karena kurangnya variasi metode yang digunakan menjadi kendaa dalam mencapai tujuan pembelajaran.

\section{Evaluasi}

Dari hasil analisis dan sintetis serta nilai rata-rata siswa di atas dapat dilihat bahwa hasil belajar siswa masih di bawah standar capain yang diharapkan, sehingga perlu dilakukan beberapa perbaikan dan perubahan pada siklus kedua. Hasil belajar mata Pelajaran Matematika Pokok Bahasan Penjumlahan Bilangan Bulat Kelas IV di SDN 04 Mamben Lauk pada siklus I dengan nilai rata-rata sebesar 6,3 menunjukkan tidak adanya peningkatan hasil belajar yang disebabkan karena beberapa aspek yang sudah dijelaskan di atas.

Oleh karena itu, peneliti melihat adanya kekurangan dan belum maksimalnya proses pembelajaran yang dilakukan, termasuk tidak terlaksana sepenuhnya perencanaan pembelajaran yang disusun dengan implementasi pembelajaran yang dilakukan. Upaya yang harus dilakukan adalah dengan menyusun rencana pembelajaran yang lebih implementatif, proses pembelajaran yang tidak kaku, serta menyusun rencana evaluasi belajar yang dilakukan pada akhir pembelajaran.

\section{Hasil Siklus II}

Setelah dilakukan beberapa perbaikan dan menyusun perencanaan pembelajaran dari awal sampai akhir pembelajaran terlihat beberapa perubahan yang ada, tentunya dapat berdampak pada hail belajar yang sesuai dengan tujuan pembelajaran. Adapun perubahan yang terjadi adalah sebagai berikut : (a) Perubahan pendekatan dan 
strategi pembelajaran yang dilakukan oleh guru seperti metode pembelajaran berpariasi yakni dengan menggunakan metode bermain, metode dialogis serta metode bermain peran. Dengan penggunaan metode ini, siswa lebih aktif dalam memerankan dirinya, diberikan kesempatan untuk menemukan sendiri, serta adanya komunikasi aktif antara siswa dengan guru. (b) Dengan menggunakan alat peraga kartu positif negatif, siswa lebih cepat menangkap pembelajaran, lebih cepat memahami isi pembelajaran serta dapat dengan mudah melakukan penjumlahan bilangan bulat. (c) Siswa lebih bersemangat dan termotivasi dalam mengikuti pelajaran. (d) Pembelajaran yang dilakukan tidak kaku, siswa dapat aktif bertanya dan menjawab pertanyaan yang ada dalam pembelajaran.

Adapun hasil penelitian yang dilakukan pada siklus II yang secara rinci dijelaskan di bawah ini :

\section{Refleksi}

Pada siklus II ini atas perencanaan pembelajaran dan perbaikan serta implementasi yang baik, dapat dilihat bahwa terjadi perubahan yang signifikan dan terlihat juga bahwa pendekatan pembelajaran yang dilakukan dapat menghidupkan kelas serta partisifasi siswa dalam proses belajar mengajar.

\section{Sintesis}

Dari hasil pelaksanaan siklus II yang dilakukan sesuai dengan perencanaan pembelajaran serta evaluasi keberhasilan belajar yang dilakukan pada akhir pembelajaran serta metode mengajar yang digunakan menunjukkan bahwa kelemahan dan kekurangan yang ada pada silkus I sudah dapat diatasi dengan baik sehingga peneliti melihat adanya keberhasilan penerapan pendekatan pembelajaran pada tindakan yang dilakukan dikelas.

\section{Evaluasi}

Menggunakan kartu positif negative menunjukkan peningkatan hasil yang baik yakni dengan melihat nilai hasil belajar siswa kelas IV SDN 04 Mamben lauk dengan rata-rata nilai sebesar 8,2. Jika dibandingkan dengan nilai rata-rata siswa pada siklus I sebesar 6,3 maka dapat dilihat besarnya perubahan hasil yang didapatkan. Sehingga peneliti dapat menarik kesimpulan bahwa penggunaan kartu 
positif negatif pada pembelajaran penjumlahan bilangan bulat berhasil dengan baik untuk meningkatkan hasil belajar siswa.

\section{Kesimpulan}

Berdasarkan hasil penelitian dan analisa data penelitian tindakan kelas pada Mata Pelajaran Matematika Pokok Bahasan Penjumlahan Bilangan Bulat Kelas IV di SDN 04 Mamben Lauk dengan menggunakan media kartu positif negatif sudah berhasil dengan melihat pelaksanaan pada siklus I dan siklus II. Nilai ratarata siswa pada siklus I yakni sebesar 6,3 dan pada siklus II nilai rata-rata siswa sebesar 8,2 menunjukkan perubahan yang signifikan.

Kemudian perencanaan pembelajaran, implementasi serta metode yang dilakukan untuk mengukur hasil belajar siswa menjadi satu rangkaian perbaikan dari siklus I yang diterapkan pada siklus II yang secara konkrit dapat meningkatkan keaktifan, kereatifitas serta hasil belajar siswa dengan menggunakan media kartu positif negatif pada penjumlahan bilangan bulat mata pelajaran matematika di SDN 04 Mamben Lauk.

\section{DAFTAR PUSTAKA}

Arikunto, dkk.2009. Penelitian Tindakan Kelas.Jakarta : Bumi Aksara

Arikunto, Suharsimi.2002.Prosedur Penelitian Suatu Pendekatan Prakek.Jakarta: Rineka Cipta

Azhar, Arsyad.2000.Media Pembelajaran.Jakarta: Rajawali Press

Depdiknas.2000.Tujuan Matematika di Sekolah Dasar.Jakarta:.depdiknas

Desmita. 2009. Strategi Perkembangan Belajar Mengajar.Jakarta:Rineka Cipta

Hamalik.oemar.1998. Psikologi Belajar Mengajar.Bandung : Sinar Baru Algensindo

Halidjah.2013. Skripsi: Peningkatan hasil belajar siswa menggunakan media kartu positif dan kartu negatif pada pembelajaran matematika kelas IV SDN 40 Nanga Taya ( FKIP Universitas Tanjung Pura Pontianak)

Roestiyah.1990. Strategi Belajar Mengajar.Jakarta:Rineka Cipta

Sukiman.2012.Pengembangan Media Pembelajaran.Yogyakarta:Pedagogia 
Sutikno Sobri, Fathurrahman Pupuh.2007.Strategi Belajar Mengajar.Bandung PT.Refika Aditama

Syah, Muhibbin.2003. Psikologi Belajar.Jakarta :PT.Rasa Grafindo Persada 